\title{
Quantitative Autoradiography Reveals Selective Changes in Cerebellar GABA Receptors of the Rat Mutant Dystonic
}

\author{
Mitchell Beales, ${ }^{1}$ Joan F. Lorden, ${ }^{2}$ Elizabeth Walz, ${ }^{1}$ and Gary A. Oltmans ${ }^{1}$ \\ 'Department of Pharmacology and Molecular Biology, The Chicago Medical School, North Chicago, Illinois 60064, and \\ 2Department of Psychology and Neurobiology Research Center, University of Alabama at Birmingham, Birmingham, \\ Alabama 35294
}

In the rat mutant dystonic ( $d t)$, glutamic acid decarboxylase (GAD) activity in the deep cerebellar nuclei (DCN) is elevated compared to normal littermates. The distribution of this increase within the DCN, and the effect upon GABA receptor density, was assessed in 25-d-old animals. GAD activity was increased 45,41 , and $74 \%$ in the medial, interpositus, and lateral divisions of the DCN, respectively. Autoradiographic analysis of $\mathrm{GABA}_{\mathrm{A}}$ receptor density, using the ligand ${ }^{3} \mathrm{H}$ muscimol (MUSC), revealed a significant decrease in MUSC binding in the DCN of the mutant. No changes in the binding of the benzodiazepine ligand ${ }^{3} \mathrm{H}$-flunitrazepam (FLU) were found in the DCN. At 18 other sites, including motor areas in the brain stem, midbrain, and forebrain, no significant changes were found in either MUSC or FLU binding. There also was a failure to find any significant changes in $d t$ animals in the binding of ligands which label the muscarinic cholinergic receptor, dopamine $\mathrm{D}_{2}$ receptor, or serotonin $5-\mathrm{HT}_{2}$ receptor. The results support earlier findings that GABAergic activity is increased in Purkinje cell terminals of the dtmutant and suggest that in response to this enhanced activity, GABA receptors in the DCN are down-regulated. At other levels of the neuraxis no consistent changes were found in any of the variables studied, suggesting that cerebellar dysfunction may be a primary component of the dystonic syndrome.

Changes in receptor density have frequently been studied following local neurotransmitter changes induced by lesions, drugs, or other manipulations (Banerjee et al., 1977; U'Prichard and Snyder, 1978; Peroutka and Snyder, 1980; U'Prichard et al., 1980; Pan et al., 1985). Recently, Rotter and Frostholm (1988) and others (Lippa et al., 1978; Skolnick et al., 1979; Sauer et al., 1984; Olson et al., 1987; Rotter et al., 1988) have reported that genetically programmed neuronal degeneration can also affect receptors. In the Purkinje cell degeneration $(p c d)$ and staggerer $(s g s g)$ mouse mutants, the appropriate Purkinje cell input from the cerebellar cortex to the deep cerebellar nuclei (DCN) is lost. In both mutants the density of the GABA/benzodiaze-

Received Sept. 13, 1989; revised Dec. 14, 1989; accepted Dec. 28, 1989

This work was supported in part by a grant from the Dystonia Medical Research Foundation and by NIH grant NS18062.

Correspondence should be addressed to Dr. Gary A. Oltmans, Department of Pharmacology and Molecular Biology, The Chicago Medical School, 3333 Green Bay Road, North Chicago, IL 60064.

Copyright (C) 1990 Society for Neuroscience $0270-6474 / 90 / 061874-12 \$ 02.00 / 0$ pine receptor complex, as labeled by ${ }^{3} \mathrm{H}$-flunitrazepam (FLI), is increased in the DCN (Rotter and Frostholm, 1988). Thus, reductions in Purkinje cell number are associated with receptor up-regulation in these mutants.

In the genetically dystonic $(d t)$ rat, we have identified biochemical abnormalities that suggest changes in Purkinje cell activity. In contrast to the mouse mutants discussed above, the cytoarchitecture of the cerebellum appears normal in the $d t$ rat (Lorden et al., 1984), but the activity of glutamic acid decarboxylase (GAD) in the DCN is elevated (Oltmans et al., 1984). GAD, the synthetic enzyme for the inhibitory transmitter GABA, is primarily localized to Purkinje cell terminals (Fonnum et al., 1970; Wassef et al., 1986) in this region. Thus, the increased GAD activity suggests enhanced Purkinje cell activity in these animals.

Despite the increase in GAD activity, single-unit recording studies in urethane-anesthetized 20-28-d-old $d t$ animals indicate that the firing rate of Purkinje cells is significantly lower in these mutants than in normal littermate controls (Stratton et al., 1988). The basis of this discrepancy is not clear. It is possible that abnormal activity occurs in the Purkinje cells of $d t$ animals primarily during dystonic episodes and that this effect is masked by anesthesia. If the Purkinje cells of the $d t$ rat are hypoactive, as suggested by the electrophysiological data, the availability of GABA, the major transmitter of these cells, may be reduced. Compensatory increases in postsynaptic GABA receptor density in the DCN might result, as in the case of the pcd and sgsg mutants. If Purkinje cell activity and/or neurotransmitter release are increased compared with controls, as measurements of GAD activity suggest, a down-regulation of receptors might follow. To evaluate these possibilities, the density of $\mathrm{G} \wedge \mathrm{B} \wedge$ / benzodiazepine receptors was measured in the DCN of 25-dold $d t$ and control rats. At this age, GAD activity has increased for at least $8 \mathrm{~d}$ in the $d t$ mutants (Oltmans et al., 1984), and compensatory receptor changes might be expected. Autoradiographic analyses of the GABA/benzodiazepine receptor complex were conducted in the DCN and also at several other levels of the neuraxis to evaluate the possibility that the $d t$ gene might produce widespread changes in these receptors. In addition, non-GABA receptor systems involved in regulating motor function were studied in selected areas to assess the integrity of these systems in the $d t$ mutant. Finally, GAD activity was measured in micropunches of the DCN and other selected motor regions to provide information on the distribution of the increased enzyme activity in animals of the same age as those in which the receptor analyses were conducted. 
Table 1. Assay conditions for autoradiographic receptor studies in dystonic rats

\begin{tabular}{|c|c|c|c|c|c|}
\hline & \multicolumn{5}{|l|}{ Receptor } \\
\hline & Muscarinic & Dopamine $\left(D_{2}\right)$ & Serotonin $\left(5 \mathrm{HT}_{2}\right)$ & $\mathrm{GABA}_{\mathrm{A}}$ & Benzodiazepine \\
\hline Ligand & $\begin{array}{l}{ }^{3} \mathrm{H} \text {-quinuclidinyl } \\
\text { benzilate }\end{array}$ & ${ }^{3} \mathrm{H}$-spiroperidol & ${ }^{3}$ H-spiroperidol & ${ }^{3} \mathrm{H}$-muscimol & ${ }^{3} \mathrm{H}$-flunitrazepam \\
\hline Specific activity & $39 \mathrm{Ci} / \mathrm{mmol}$ & $85 \mathrm{Ci} / \mathrm{mmol}$ & $85 \mathrm{Ci} / \mathrm{mmol}$ & $5.2-13.8 \mathrm{Ci} / \mathrm{mmol}$ & $81-81.8 \mathrm{Ci} / \mathrm{mmol}$ \\
\hline Reference(s) & $\begin{array}{l}\text { Wamsley et al., } \\
1981\end{array}$ & $\begin{array}{l}\text { Richfield et al., } \\
\text { 1986; Palacios } \\
\text { et al., } 1981\end{array}$ & $\begin{array}{l}\text { Richfield et al., } \\
\text { 1986; Palacios } \\
\text { et al., } 1981\end{array}$ & Penney et al., 1981 & Pan et al., 1984 \\
\hline Buffer & $\begin{array}{l}50 \text { mM sodium } \\
\text { phosphate buffer }\end{array}$ & $\begin{array}{l}170 \text { mMTris } \mathrm{HCl} \\
\mathrm{pH} 7.7 \text { at } 22^{\circ} \mathrm{C}^{a . b}\end{array}$ & $\begin{array}{l}170 \mathrm{~mm} \text { Tris } \mathrm{HCl} \\
\text { pH } 7.7 \text { at } 22^{\circ} \mathrm{C}^{u}\end{array}$ & $\begin{array}{l}50 \mathrm{~mm} \text { Tris citrate, } \\
\mathrm{pH} 7.0 \text { at } 0^{\circ} \mathrm{C}\end{array}$ & $\begin{array}{c}50 \mathrm{~mm} \text { Tris } \mathrm{HCl} \\
\text { pH } 7.4 \text { at } 0^{\circ} \mathrm{C}\end{array}$ \\
\hline [Ligand] & $1 \mathrm{~nm}$ & $0.8 \mathrm{nM}$ & $0.8 \mathrm{~nm}$ & $100 \mathrm{~nm}$ & $15 \mathrm{~nm}$ \\
\hline Competitor & $1 \mu \mathrm{M}$ atropine & $100 \mu \mathrm{M}$ dopamine & $100 \mathrm{~nm}$ mianserin & $100 \mu \mathrm{M}$ GABA & $15 \mu \mathrm{M}$ clonazepam \\
\hline Prewash & $\begin{array}{l}2 \times 5 \mathrm{~min} \text { in } \\
\text { buffer at } 22^{\circ} \mathrm{C}\end{array}$ & $\begin{array}{l}2 \times 5 \text { min in } \\
\text { buffer at } 22^{\circ} \mathrm{C}\end{array}$ & $\begin{array}{l}2 \times 5 \mathrm{~min} \text { in } \\
\text { buffer at } 22^{\circ} \mathrm{C}\end{array}$ & $\begin{array}{l}3 \times 5 \text { min in } \\
\text { buffer at } 0-4^{\circ} \mathrm{C}\end{array}$ & $\begin{array}{l}3 \times 5 \mathrm{~min} \text { in } \\
\text { buffer at } 0-4^{\circ} \mathrm{C}\end{array}$ \\
\hline Incubation & $120 \mathrm{~min}$ at $22^{\circ} \mathrm{C}$ & $60 \mathrm{~min}$ at $22^{\circ} \mathrm{C}$ & $60 \mathrm{~min}$ at $22^{\circ} \mathrm{C}$ & 30 min at $0-4^{\circ} \mathrm{C}$ & 30 min at $0-4^{\circ} \mathrm{C}$ \\
\hline Postwash & $\begin{array}{l}2 \times 5 \text { min in } \\
\text { buffer at } 0-4^{\circ} \mathrm{C} \text {, } \\
\text { then dip in } \mathrm{H}_{2} \mathrm{O}\end{array}$ & $\begin{array}{l}2 \times 5 \text { min in } \\
\text { buffer at } 0-4^{\circ} \mathrm{C} \\
\text { then dip in } \mathrm{H}_{2} \mathrm{O}\end{array}$ & $\begin{array}{l}2 \times 5 \mathrm{~min} \text { in } \\
\text { buffer at } 0-4^{\circ} \mathrm{C}, \\
\text { then dip in } \mathrm{H}_{2} \mathrm{O}\end{array}$ & $\begin{array}{l}3 \times 3 \mathrm{sec} \text { in } \\
\text { buffer at } 0-4^{\circ} \mathrm{C} \text {, } \\
\text { then dip in } \mathrm{H}_{2} \mathrm{O}\end{array}$ & $\begin{array}{l}2 \times 2 \text { min in } \\
\text { buffer at } 0-4^{\circ} \mathrm{C}, \\
\text { then dip in } \mathrm{H}_{2} \mathrm{O}\end{array}$ \\
\hline
\end{tabular}

Buffer also contained: $120 \mathrm{~mm} \mathrm{NaCl}, 5 \mathrm{~mm} \mathrm{KCl}, 1 \mathrm{~mm} \mathrm{MgCl}, 2 \mathrm{mM} \mathrm{CaCl}, 0.001 \%$ ascorbic acid, and $1 \mu \mathrm{M}$ pargyline.

Buffer also contained $100 \mathrm{~nm}$ mianserin.

Buffer also contained $100 \mu \mathrm{M}$ dopamine.

\section{Materials and Methods}

Twenty-five-d-old dystonic animals and their normal littermates were obtained from the colony maintained at the University of Alabama at Birmingham. The animals were killed by decapitation and the brains removed and frozen in isopentane cooled to $-25^{\circ} \mathrm{C}$ with dry ice. This procedure produces rapid freezing of the brain while maintaining good morphological integrity. All brains were maintained frozen $\left(-70^{\circ} \mathrm{C}\right)$ until processed for autoradiographic analysis or determination of GAD activity.

$G A D$ assay. GAD activity was determined in cerebellar and midbrain motor nuclei of $d t$ rats and their normal littermate controls. Samples were obtained using minor modifications of the punch technique of Palkovits (1973). In brief, $300 \mu \mathrm{m}$ frozen coronal sections containing the structures of interest were mounted on glass slides by briefly thawing the section and immediately refreezing on dry ice. The medial, interpositus, and lateral divisions of the cerebellar nuclei, the pontine nuclei, and the substantia nigra were removed from the frozen sections with an 18- or 21-gauge ncedle (internal diameters, 0.8 and $0.5 \mathrm{~mm}$, respectively) using the atlas of Paxinos and Watson (1986) as a guide. Tissue samples were immediately frozen in $100 \mu \mathrm{l}$ of a $100 \mathrm{mM} \mathrm{KCl}$, $3.3 \mathrm{mM} \mathrm{Na}_{2}$ EDTA, $0.5 \%$ Triton X-100 solution, and were maintained frozen at $-70^{\circ} \mathrm{C}$ until assayed for GAD activity.

To measure GAD activity, samples were thawed, homogenized by sonication, and duplicate $25 \mu \mathrm{l}$ aliquots assayed using minor modifications of previously described procedures (Oltmans et al., 1984, 1986). In the current studies, the concentrations of substrate and cofactor in the incubation mixture were increased to $100 \mathrm{~mm}$ glutamate $(25 \mu \mathrm{Ci}$ / mmol) and $200 \mu \mathrm{M}$ pyridoxal phosphate, respectively. Preliminary studies indicated that these concentrations produced maximal GAD activity. All values are reported as nmol GABA $/ \mathrm{mg}$ protein $/ \mathrm{hr}$. Proteins were determined using a modification of the method of Lowry et al. (1951; Larson et al., 1986). Reported values are means \pm SD.

Receptor autoradiography. Autoradiographic studies of receptor density were conducted in a separate group of animals. To prepare tissue for sectioning, the brains were removed from the freezer and warmed overnight in a cryostat $\left(-12^{\circ} \mathrm{C}\right)$. Ten micron frontal sections were cut, thaw-mounted on clean glass slides, and immediately dried to translucence on the palm of the hand. Sections processed in this way adhered well to the slides during the assays eliminating the need for subbed slides. Fourteen consecutive sections were taken at each of 8 levels of section, chosen to sample the structures labeled in Figure 1. These approximated the levels shown in plates $71,64,47,40,33,29,24$, and
15 in the atlas of Paxinos and Watson (1986). The dried sections were stored in slide boxes with dessicant at $-20^{\circ} \mathrm{C}$ until they were assayed.

Autoradiographic assays for $\mathrm{GABA}_{\mathrm{A}}$, benzodiazepine (BZD), muscarinic cholinergic, dopamine $\mathrm{D}_{2}$, and serotonin $5-\mathrm{HT}_{2}$ receptors were conducted according to previously published methods employing ligands, wash and incubation conditions, and displacers as detailed in Table 1. In general, slide-mounted tissue sections were removed from the freezer, prewashed in a buffer solution to remove endogenous ligands, and incubated with saturating concentrations of the specific radioligand (DuPont/NEN or Amersham) for the selected receptor to yield estimates of receptor density. Nonspecific binding was determined by addition of an appropriate antagonist to the incubation solution. Following incubation, the sections were rinsed in buffer to remove unbound radiolabel, dipped in $\mathrm{H}_{2} \mathrm{O}$ to remove buffer salts, then rapidly dried $(<30 \mathrm{sec})$ in a stream of warm air.

In some assays, deviations from the above general procedure were required. In the ${ }^{3} \mathrm{H}$-muscimol (MUSC) and the FLU assays, two 5-min mini-incubations in radiolabeled solutions (using final incubation concentrations of the respective ligands) were interposed between the initial buffer washes and the final $30 \mathrm{~min}$ incubation. This allowed solutions to be used for several groups of sections without producing detectable changes in radioligand concentration in the final incubation mixture. This procedure was employed to reduce the total quantity of expensive radioligand required to saturate the receptors. Sections from $d t$ and control animals were incubated simultaneously in the same coplin jar to insure that slight variations in the composition of the incubation solution would not bias the results.

The $\mathrm{D}_{2}$ and $5-\mathrm{HT}_{2}$ receptors were both analyzed with the ligand ${ }^{3} \mathrm{H}-$ spiroperidol (SPIRO), but using different incubation conditions. The $\mathrm{D}_{2}$ receptor binding was defined as the SPIRO binding in the presence of $100 \mathrm{~nm}$ mianserin, which could be displaced by $100 \mu \mathrm{M}$ dopamine. Similarly, the $5-\mathrm{HT}_{2}$ receptor binding was defined as SPIRO binding in the presence of $100 \mu \mathrm{M}$ dopamine, which could be displaced by $100 \mathrm{nM}$ mianserin. Nonspecific binding, the binding remaining in the presence of both $100 \mu \mathrm{M}$ dopamine and $100 \mathrm{~nm}$ mianserin, was determined for both receptors in a single section. This procedure reduces the overestimates of receptor number which are likely to occur with a ligand such as SPIRO, which lacks specificity for a single receptor.

The radiolabeled sections were exposed to Ultrofilm ${ }^{3} \mathrm{H}(\mathrm{LKB})$ or Hyperfilm ${ }^{3} \mathrm{H}$ (Amersham) along with brain paste standards (Unnerstall et al., 1981) for $10-45 \mathrm{~d}$ at room temperature. Exposure time varied depending on the specific activity of the ligand and receptor density in the areas of major interest at different levels of section. All samples 

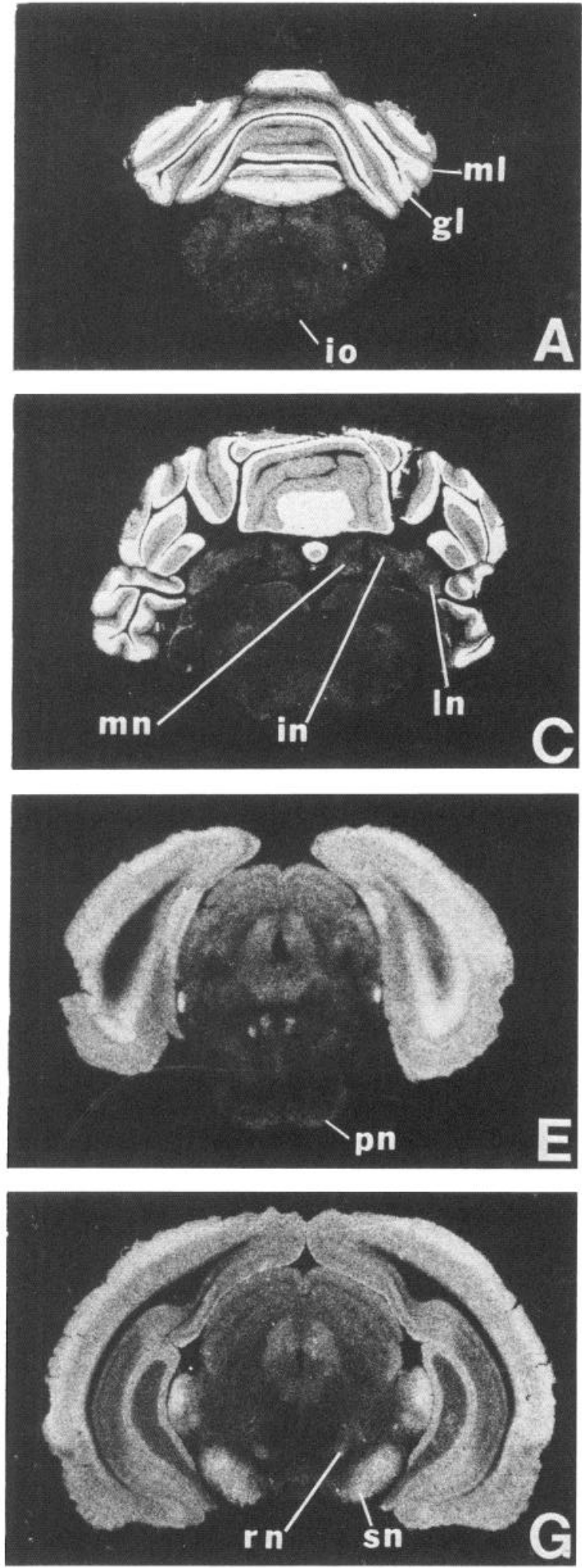
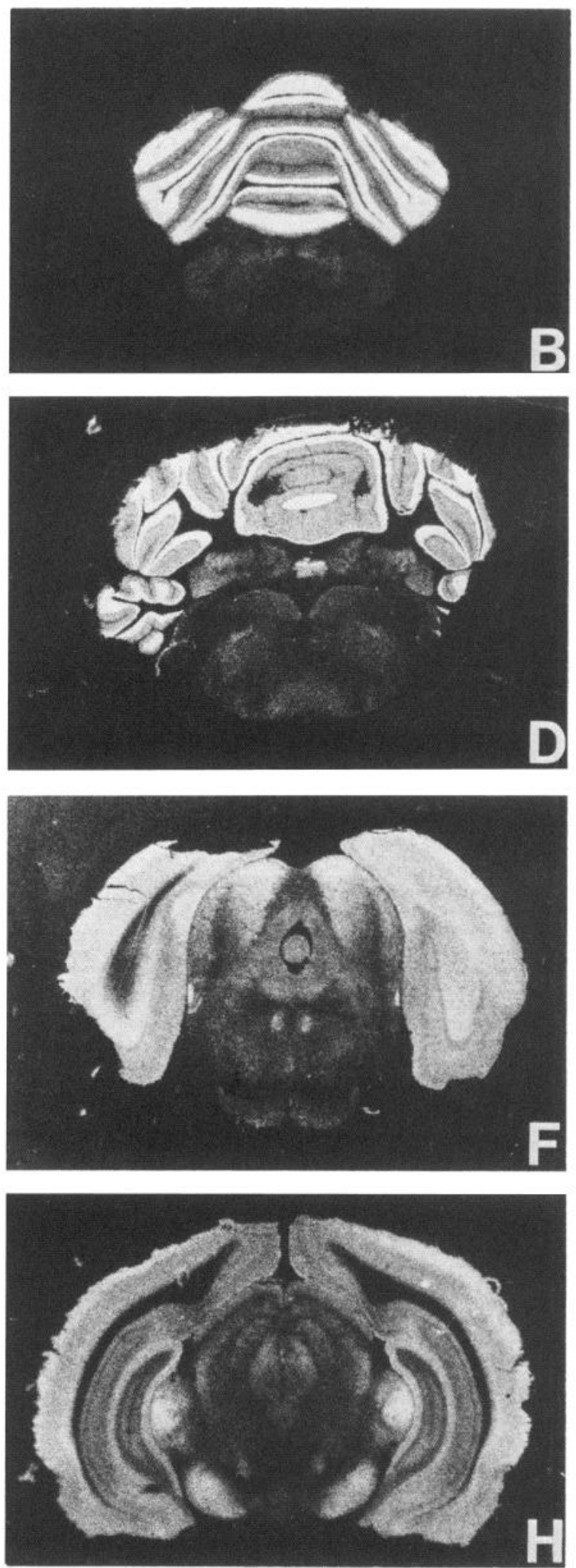

Figure 1. ${ }^{3} \mathrm{H}$-muscimol (100 $\mathrm{nm}$ ) binding in matched brain sections from dt rats (left column) and normal littermate controls (right column). For all the figures, the original autoradiograms were used as negatives to prepare enlarged prints, thus, brighter areas represent greater binding. Nonspecific binding (not shown), measured in the presence of $100 \mu \mathrm{M}$ GABA, was lower than for ${ }^{3} \mathrm{H}$-flunitrazepam (Fig. $2 B$ ) and was barely detectable. The binding patterns in $d t$ and normal rats were similar in all areas except the cerebellar nuclei $(C, D)$, where binding was significantly lower in the $d t$ 

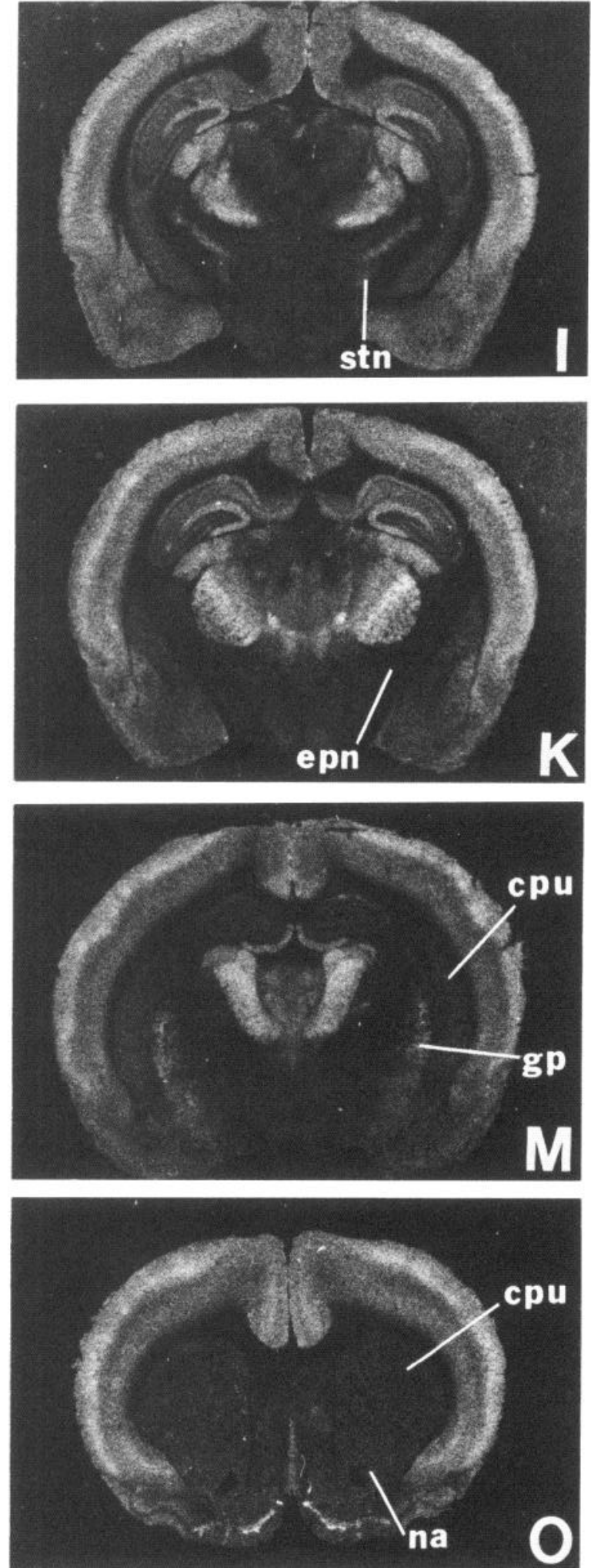
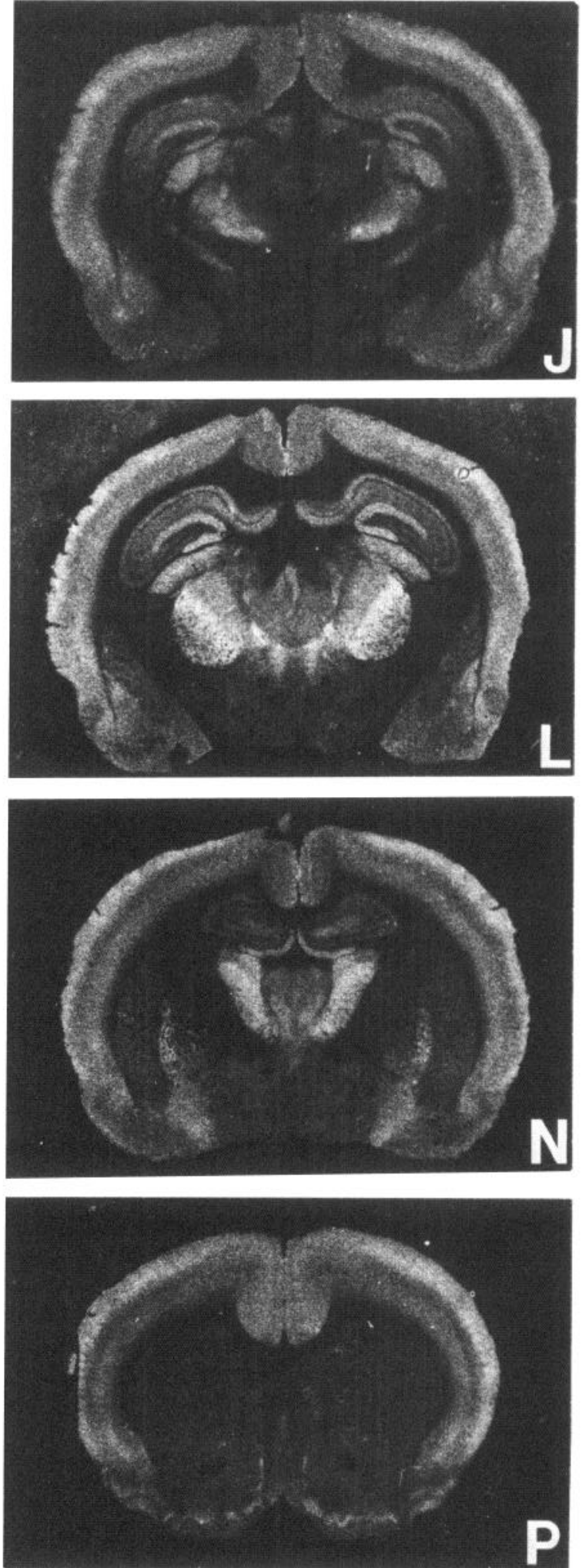

rat. Abbreviations: $c p u$, caudate putamen; $e p n$, entopeduncular nucleus; $g p$, globus pallidus; $g l$, granular layer; $i o$, inferior olive; in, interpositus nucleus; $l n$, lateral nucleus; $m n$, medial nucleus; $m l$, molecular layer; $n a$, nucleus accumbens; $p n$, pontine nuclei; $r n$, red nucleus; $s n$, substantia nigra; $s t n$, subthalamic nucleus. 
Table 2. GAD activity in the deep cerebellar nuclei and other selected motor nuclei of 25 -d-old dystonic and normal rats (mean \pm SD)

\begin{tabular}{lrlll} 
& \multicolumn{5}{l}{ GAD activity $(\mathrm{nmol} / \mathrm{mg}$ protein $/ \mathrm{hr})$} \\
\cline { 2 - 5 } Brain area & \multicolumn{3}{c}{ Dystonic $(N)$} & \% Normal \\
\hline Deep cerebellar nuclei & $183.0 \pm 58.9(11)$ & $266.2 \pm 43.0^{\circ}$ & $(12)$ & 145 \\
$\quad$ Medial & $238.6 \pm 53.5(11)$ & $336.3 \pm 61.0^{\prime \prime}$ & $(12)$ & 141 \\
$\quad$ Interpositus & $231.9 \pm 50.8(11)$ & $402.9 \pm 143.3^{\circ}(12)$ & 174 \\
$\quad$ Lateral & $54.3 \pm 26.7(10)$ & $72.0 \pm 32.7 \quad(12)$ & 133 \\
Pontine nuclei & $445.4 \pm 155.5(11)$ & $484.3 \pm 98.1$ & $(12)$ & 109 \\
Substantia nigra & &
\end{tabular}

“ Differs significantly from normal littermate control $(p<0.05)$

labeled with a specific ligand at a single level of section were, however, treated identically. Film was developed for $5 \mathrm{~min}$ in Kodak D-19 at $20^{\circ} \mathrm{C}$, fixed for $5 \mathrm{~min}$ in Ektaflow fixer (Kodak), and washed for $20 \mathrm{~min}$.

A computer-based image-analysis system (QUANDENS, Fred Haer Co.) was used to analyze the autoradiograms. A digital image of specific binding was generated for each pair of total and nonspecific autoradiograms by subtracting the digitized nonspecific binding autoradiogram from the digitized total binding autoradiogram. The average digital transmittance was calculated from the specific binding image for each area of interest. A similarly calculated digital transmittance value for a fully exposed film was subtracted from values for each area (to compensate for the lack of a dark current adjustment in the image capture video system) to yield an adjusted transmittance value $(T)$. The logit of the adjusted percent transmittance value $\left(T / T_{\max }\right)$ for each tissue paste standard was then plotted against the natural logarithm of the DPM/ mg protein determined for that standard (see Pan et al., 1983). This procedure yielded standard curves which were linear for standards for which values of $T$ bracketed those calculated for the sample brain sections. Receptor values are reported as $\mathrm{pmol} / \mathrm{mg}$ protein (mean $\pm \mathrm{SD}$ ) for all ligands except SPIRO, for which values are reported as $\mathrm{fmol} / \mathrm{mg}$ protein.

Data analysis. Data were analyzed using an analysis of variance (ANOVA). In most instances, related functional or structural groups (e.g. basal ganglia) were grouped together and analyzed using a 2-way ANOVA (genotype by nucleus). In the cerebellar cortex, data were analyzed using a 3-way ANOVA (genotype by level of section by layer). Specific comparisons between cell means were made using Duncan's multiplerange test. In some instances, where a specific structure did not readily fall into a functional group (e.g., pontine nucleus, red nucleus), dystonic and normal animals were compared directly by means of a $t$-test.

\section{Results}

GAD activity in the cerebellum and selected motor nuclei

GAD activity was measured in the individual divisions of the DCN of 25 -d-old $d t$ rats. In confirmation of previous reports (Oltmans et al., 1984), a significant effect of genotype on GAD activity in the DCN was found $\left(F_{1,63}=39.7, p<0.001\right)$. Followup tests revealed significant increases in GAD activity in each of the 3 divisions of the DCN (medial, interpositus, lateral) (Table 2). In comparison with 20-d-old animals studied previously (Oltmans et al., 1984, 1986), the magnitude of the change in GAD activity in the 25 -d-old animals appeared larger $( \pm 53$ vs $\pm 25 \%$ ).

GAD activity was also examined in the pontine nuclei and substantia nigra. In the pontine nuclei, enzyme activity was low but measurable, and in the substantia nigra, GAD activity was the highest of any area examined in this study (Table 2). GAD activity in the $d t$ rats did not differ from normal littermatc controls in either of these areas, suggesting that the changes found in the cerebellum are not the result of a generalized defect in GAD (see also Oltmans et al., 1984).

\section{GABA receptor autoradiography}

\section{${ }^{3} \mathrm{H}$-muscimol binding}

In both normal and $d t$ animals, MUSC binding in the cerebellum followed the pattern previously reported for normal animals (Palacios et al., 1980; Frostholm and Rotter, 1987; Herkenham, 1987; Fig. 1, Table 3). Binding density in the granular layer of the cerebellar cortex was higher than in the molecular layer $\left(F_{1.60}\right.$ $=1258, p<0.001$ ), and both of these regions had higher binding than the DCN. In all 3 areas, however, binding could be readily quantified.

In the cerebellar cortex, hinding was examined at 2 levels of section, one through the paramedian lobule and one through the ansiform lobule. The statistical analysis did not reveal a significant effect of either genotype or level of section on binding density, but a significant genotype by level interaction was found $\left(F_{1.60}=12.6, p<0.001\right)$. Follow-up analysis indicated significantly less binding in the granular layer of the ansiform lobule of the $d t$ rats than in the normal littermate controls.

Several changes in MUSC binding were found in the DCN. There was a significant main effect of genotype on binding $\left(F_{1.42}\right.$ $=20.2, p<0.001)$, and follow-up analyses revealed significant decreases in binding in the lateral $(-21 \%)$ and interpositus $(-23 \%)$ nuclei of the $d t$ mutants, with a smaller decrease $(-16 \%)$ in the medial nucleus (Fig. 1, Table 3). The analysis also indicated significant medial-to-latcral differences in receptor density in both $d t$ and normals, with the lateral nucleus showing a higher receptor density than either the interpositus or medial nucleus.

MUSC binding was also examined in 18 other brain regions, including several motor areas such as the pontine nuclei, red nucleus, and basal ganglia (Fig. 1, Table 3). Binding density in the pontine nuclei and red nucleus did not differ between $d t$ and controls, although the difference in the pontine nuclei did approach statistical significance $\left(+15 \%, t_{14}=1.91, p<0.08\right)$. In the basal ganglia, the ANOVA did not reveal a significant effect of genotype. However, the largest percentage change in receptor density for any brain area examined was found in the globus pallidus $(+27 \%)$. Direct comparison of cell means for normal and $d t$ rats for this structure did suggest a difference $\left(t_{18}=2.2\right.$, $p<0.05)$.

In the thalamus there was a significant difference in receptor binding among the various thalamic nuclei $\left(F_{8.135}=93, p<\right.$ 0.001 ), but no difference between $d t$ and normals. The differential binding densities between the nuclei made thalamic divisions which are barely discernible in Nissl-stained sections 


\begin{tabular}{|c|c|c|c|}
\hline \multirow[b]{2}{*}{ Brain area or level } & \multicolumn{3}{|c|}{${ }^{3} \mathrm{H}$-muscimol binding (pmol/mg protein) } \\
\hline & Normal littermate $(N)$ & Dystonic $(N)$ & $\%$ Normal \\
\hline \multicolumn{4}{|l|}{ Cerebellum } \\
\hline \multicolumn{4}{|l|}{ Molecular layer } \\
\hline Paramedian lobule & $3.52 \pm 0.41(9)$ & $4.37 \pm 0.42(9)$ & 124 \\
\hline Ansiform lobule & $4.01 \pm 0.56(8)$ & $3.92 \pm 0.50(8)$ & 98 \\
\hline \multicolumn{4}{|l|}{ Granule layer } \\
\hline Paramedian lobule & $11.28 \pm 0.76(9)$ & $11.73 \pm 1.24(9)$ & 104 \\
\hline Ansiform lobule & $11.75 \pm 1.21(8)$ & $10.21 \pm 1.17^{b}(8)$ & 87 \\
\hline \multicolumn{4}{|l|}{ Deep cerebellar nuclei } \\
\hline Medial & $1.25 \pm 0.28(8)$ & $1.05 \pm 0.18$ & 84 \\
\hline Interpositus & $1.43 \pm 0.24(8)$ & $1.10 \pm 0.15^{b}(8)$ & 77 \\
\hline Lateral & $2.01 \pm 0.35(8)$ & $1.58 \pm 0.23^{h}(8)$ & 79 \\
\hline \multicolumn{4}{|l|}{ Midbrain-brain stem } \\
\hline Pontine nuclei & $1.34 \pm 0.19(7)$ & $1.54 \pm 0.22$ & 115 \\
\hline Red nucleus & $2.46 \pm 0.47(10)$ & $2.26 \pm 0.54(9)$ & 92 \\
\hline Substantia nigra & $5.12 \pm 0.92(10)$ & $5.13 \pm 0.57(10)$ & 100 \\
\hline \multicolumn{4}{|l|}{ Thalamus-thalamic nuclei } \\
\hline Parafascicular & $1.32 \pm 0.27(5)$ & $1.42 \pm 0.23$ & 108 \\
\hline Posterior & $4.03 \pm 0.35(9)$ & $3.99 \pm 0.63(9)$ & 99 \\
\hline Ventrolateral & $4.28 \pm 0.42(9)$ & $4.19 \pm 0.51(9)$ & 98 \\
\hline Ventromedial & $2.51 \pm 0.38(9)$ & $2.80 \pm 0.54$ & 112 \\
\hline Ventral posterolateral & $3.25 \pm 0.22(9)$ & $3.42 \pm 0.47(9)$ & 105 \\
\hline Ventral posteromedial & $5.18 \pm 0.36(9)$ & $5.13 \pm 0.64$ & 99 \\
\hline Gelatinosus & $3.93 \pm 1.11(9)$ & $4.08 \pm 1.06(9)$ & 104 \\
\hline Dorsolateral geniculate & $3.65 \pm 0.54(10)$ & $3.99 \pm 0.54$ & 109 \\
\hline Ventrolateral geniculate & $1.02 \pm 0.13(10)$ & $1.10 \pm 0.15$ & 108 \\
\hline \multicolumn{4}{|l|}{ Basal ganglia } \\
\hline Caudate putamen & $1.09 \pm 0.19(11)$ & $1.21 \pm 0.25$ & 111 \\
\hline Globus pallidus & $1.86 \pm 0.48(10)$ & $2.36 \pm 0.51(10)$ & 127 \\
\hline Subthalamic nucleus & $1.85 \pm 0.42(9)$ & $1.74 \pm 0.32$ & 94 \\
\hline Entopeduncular nucleus & $0.93 \pm 0.30(9)$ & $0.90 \pm 0.39$ & 97 \\
\hline \multicolumn{4}{|l|}{ Cortex $^{a}$} \\
\hline Frontal cortex & $3.31 \pm 0.44(11)$ & $3.85 \pm 0.70(9)$ & 116 \\
\hline Parietal cortex & $4.38 \pm 0.76(10)$ & $4.80 \pm 1.10(10)$ & 110 \\
\hline
\end{tabular}

"Frontal cortex sections contained parts of frontal cortex areas 1-3 which are primarily motor cortex. Parietal cortex sections contained parietal cortex areas 1 and 2 and parietal cortex hindlimb area, which are primarily sensorimotor cortex (see Zilles and Wree, 1985).

Differs significantly from normal littermate control $(p<0.05)$.

(e.g., Jones, 1985) appear distinct (Fig. 1). In the cerebral cortex, no differences were found between normal and $d t$ rats.

\section{${ }^{3}$-flunitrazepam binding}

FLU was used to study the BZD component of the $\mathrm{GABA}_{A}$ receptor complex. As others have reported (Young and Kuhar, 1979; Unnerstall et al., 1981; Rotter and Frostholm, 1986), binding in the molecular layer was higher than in the granular layer $\left(F_{1.72}=280, p<0.001\right.$; Fig. 2 , Table 4$)$, the reverse of the paltern found for MUSC binding. In the DCN, receptor density was intermediate to that in the granular and molecular layer. No significant differences between normal and $d t$ animals were found in either the cerebellar cortex or DCN. The ANOVA did reveal significant differences between nuclei $\left(F_{2.54}=14.3, p<\right.$ 0.001 ), as receptor density in the lateral nucleus was significantly higher than in either of the other 2 divisions in both $d t$ and normal animals. This pattern was similar to that of MUSC binding in the DCN.
FLU binding density was also determined in 18 other brain regions, including both motor and nonmotor structures (Table 4). Comparison of $d t$ and normal animals did not reveal any significant differences between the 2 groups in any of the structures studied. As with MUSC binding, the percentage change in FLU binding in the globus pallidus $(+18 \%)$ was the largest observed in any brain region (Table 4 ), and comparison of cell means approached statistical significance $\left(t_{17}=2.07, p<0.06\right)$. Taken together, the MUSC and FLU results suggest that additional study of the effect of the $d t$ mutation on GABAergic transmission in the globus pallidus is warranted.

\section{Muscarinic acetylcholine, serotonin, and dopamine autoradiography}

The muscarinic cholinergic receptor was studied using the ligand ${ }^{3} \mathrm{H}$-quinuclidinyl benzilate (QNB). Binding assays were conducted, and autoradiograms prepared, for the same levels of section as for MUSC and FLU with the exception of the sections 

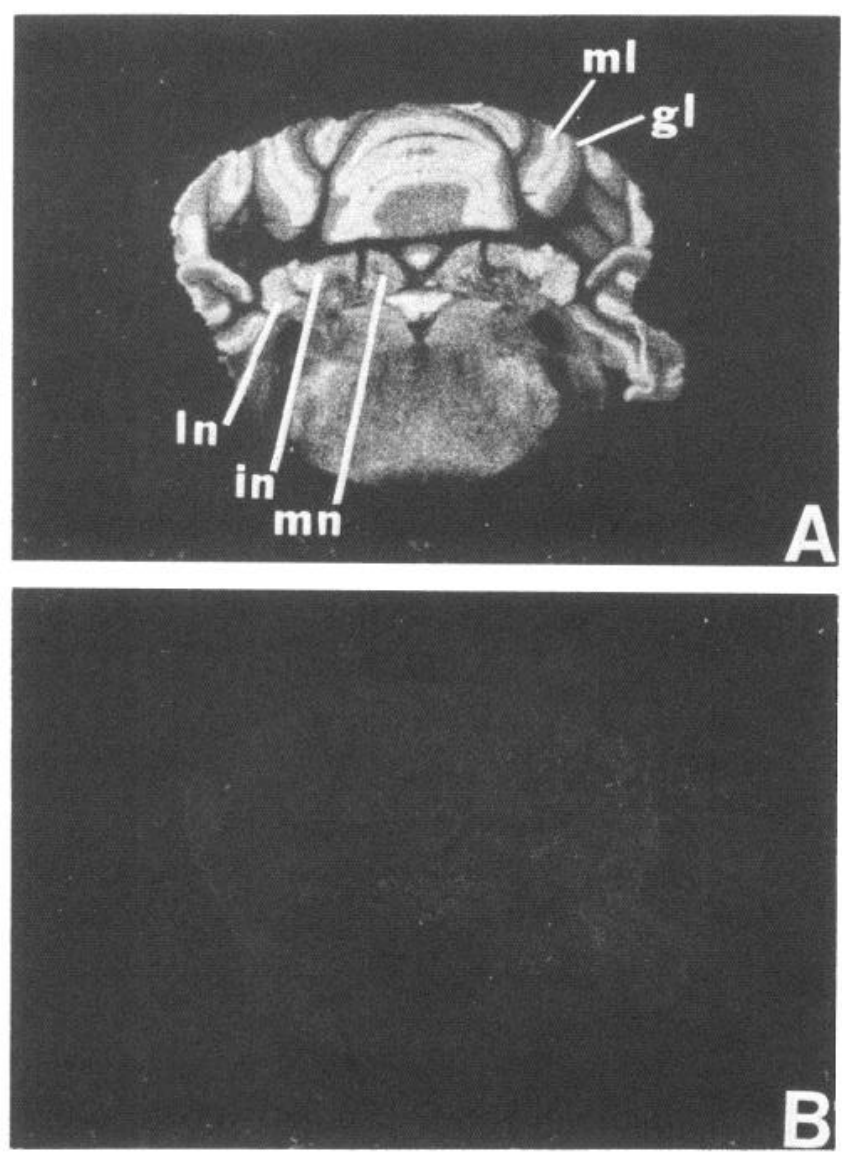

Figure 2. ${ }^{3} \mathrm{H}$-flunitrazepam binding in a section through the cerebellum of a normal 25 -d-old rat. $A$, Total binding following a $30 \mathrm{~min}$ incubation with $15 \mathrm{~nm}$ FLU. $B$, Nonspecific binding measured in the presence of $15 \mu \mathrm{M}$ clonazepam. FLU binding was higher in the molecular layer than in the granule layer, the reverse of the pattern seen with MUSC binding (see Fig. 1D). No differences in FLU binding were found between normal and $d t$ rats at any level of section. See Figure 1 for abbreviations.

through the cerebellum. In a number of regions, however, QNB binding was too sparse or too similar in adjacent structures to allow accurate quantification of binding to a particular structure. Values for many of these structures are not presented. In other areas, including both motor and nonmotor structures, binding was prominent. This range in binding densities is presented in Figure 3 , where distinct binding in the pons and caudate putamen can be contrasted with a virtual absence of binding in the substantia nigra. No significant differences between $d t$ rats and normal littermates were found in any of the structures examined (Table 5).

Serotonin 5- $\mathrm{HT}_{2}$ and dopamine $\mathrm{D}_{2}$ receptors were examined in the caudate putamen, nucleus accumbens, and cerebral cortex using SPIRO (Fig. 4). The highest levels of dopamine displaceable SPIRO binding were found in the caudate putamen followed closely by the nucleus accumbens, with cortical levels substantially lower. None of the areas analyzed showed significant differences between $d t$ and normal rats in either dopamine or mianserin displacement of the SPIRO binding (Table 6), indicating that the $\mathrm{D}_{2}$ and $5-\mathrm{HT}_{2}$ receptors in these structures are not affected by the $d t$ mutation.

\section{Discussion}

The results confirm and extend previous reports that GAD activity in the DCN of $d t$ rats is increased (Oltmans et al., 1984, 1986). In the 25-d-old rats, enzymatic activity was higher in all 3 divisions of the DCN of $d t$ rats than in normal littermates, and the magnitude of the difference was greater than that previously found in 16 - and 20 -d-old rats. The receptor studies revealed that the increased enzyme activity in $d t$ rats is accompanied by significantly reduced density of $\mathrm{GABA}_{\mathrm{A}}$ receptors in the DCN. Differences between normal and $d t$ rats on both measures, however, were confined to the cerebellum. In other areas, with the tentative exception of the globus pallidus, no differences between $d t$ and normal littermates were found in either GAD activity or $\mathrm{GABA}_{\mathrm{A}}$ receptor binding. Thus, there is no evidence that the $d t$ mutation produces a generalized defect in either GAD or the $\mathrm{GABA}_{\mathrm{A}}$ receptor. Rather, these findings suggest that there is a selective change in GABAergic activity in the cerebellum. The most plausible interpretation of the data seems to be that the elevated GAD activity reflects enhanced activity in the Purkinje cell terminals which constitute the unique and massive projection from the cerebellar cortex to the DCN. As a consequence, GABA receptors in the DCN are down-regulated.

The disparate levels of MUSC and FLU binding in the 2 layers of the cerebellar cortex replicated previous findings. In the DCN, $d t$ rats showed a significant $20 \%$ decrease in MUSC binding but no change in FLU binding compared to their normal littermates. While a differential binding pattern for 2 ligands which purportedly label the same receptor complex may seem paradoxical, current models of the $\mathrm{GABA}_{\mathrm{A}}$ receptor complex can readily accommodate such results. This complex includes $2 \alpha$ - and $2 \beta$-subunits with binding sites for FLU and MUSC, respectively (Schwartz, 1988; Stephenson, 1988). Several isoforms of each of these subunits have been discovered, and evidence from in situ hybridization studies indicates that the expression of these isoforms varies across brain regions (Hebebrand et al., 1988; Levitan et al., 1988b; Siegel, 1988; Wisden et al., 1988, 1989; Fuchs and Sieghart, 1989). There is also evidence that a functional GABA-gated chloride channel can be composed of various combinations of the different subunits (Blair et al., 1988; Levitan et al., 1988a), and studies of GABA receptors expressed in human embryonic kidney cells indicate that a GABA-sensitive site capable of chloride conductance can exist in the absence of FLU binding (MUSC binding was present) (Pritchett et al., 1988). Thus, the mechanism for the modification of postsynaptic sensitivity to GABA may include the independent regulation of individual receptor components. $\mathrm{Li}$ gand binding patterns would then depend upon the particular receptor subunits expressed in specific regions. Such a mechanism could account both for the FLU and MUSC binding patterns seen in the cerebellar cortex, and the selective change in MUSC binding found in the DCN in the current study.

Previous studies of the $\mathrm{GABA}_{\mathrm{A}}$ receptor complex in the DCN of adult animals indicated that the BZD binding site predominates, with minimal binding found at the MUSC-labeled site (Bowery et al., 1987; Herkenham, 1987). In mice, Frostholm and Rotter (1987) reported moderate MUSC binding in the DCN of young animals, but much lower binding in adults. This suggests that the level of MUSC binding in the DCN may vary with age. Other studies have shown that, in the cerebellum, GABA receptor subunit composition (Fuchs and Sieghart, 1989), BZD receptor subtypes (Garrett and Tabakoff, 1985; Sieghart, 
Table 4. Benzodiazepine receptor density in 25-d-old dystonic and normal rats using the ligand 'Hflunitrazepam (mean $\pm \mathrm{SD}$ )

${ }^{3} \mathrm{H}$-flunitrazepam binding (pmol/mg protein)

\begin{tabular}{|c|c|c|c|}
\hline Brain area or level & Normal littermate $(N)$ & Dystonic $(N)$ & $\%$ Normal \\
\hline \multicolumn{4}{|l|}{ Cerebellum } \\
\hline \multicolumn{4}{|l|}{ Molecular layer } \\
\hline Paramedian lobule & $0.74 \pm 0.14(10)$ & $0.66 \pm 0.14(10)$ & 89 \\
\hline Ansiform lobule & $0.71 \pm 0.17(10)$ & $0.80 \pm 0.15(10)$ & 113 \\
\hline \multicolumn{4}{|l|}{ Granule layer } \\
\hline Paramedian lobule & $0.28 \pm 0.04(10)$ & $0.25 \pm 0.04(10)$ & 89 \\
\hline Ansiform lobule & $0.34 \pm 0.07(10)$ & $0.35 \pm 0.05(10)$ & 103 \\
\hline \multicolumn{4}{|l|}{ Deep cerebellar nuclei } \\
\hline Medial & $0.43 \pm 0.07(10)$ & $0.49 \pm 0.07(10)$ & 114 \\
\hline Interpositus & $0.50 \pm 0.08(10)$ & $0.53 \pm 0.09(10)$ & 106 \\
\hline Lateral & $0.60 \pm 0.12(10)$ & $0.63 \pm 0.11(10)$ & 105 \\
\hline \multicolumn{4}{|l|}{ Midbrain-brain stem } \\
\hline Pontine nuclei & $0.40 \pm 0.08(10)$ & $0.43 \pm 0.06(10)$ & 108 \\
\hline Red nucleus & $0.99 \pm 0.22(10)$ & $0.93 \pm 0.21(10)$ & 94 \\
\hline Substantia nigra & $1.43 \pm 0.26(10)$ & $1.48 \pm 0.27(10)$ & 103 \\
\hline \multicolumn{4}{|l|}{ Thalamus-thalamic nuclei } \\
\hline Parafascicular & $0.66 \pm 0.14(6)$ & $0.60 \pm 0.18(5)$ & 91 \\
\hline Posterior & $0.53 \pm 0.11(10)$ & $0.51 \pm 0.09(10)$ & 96 \\
\hline Ventrolateral & $0.58 \pm 0.12(10)$ & $0.55 \pm 0.11(10)$ & 95 \\
\hline Ventromedial & $0.67 \pm 0.14(10)$ & $0.72 \pm 0.10(10)$ & 107 \\
\hline Ventral posterolateral & $0.41 \pm 0.07(10)$ & $0.42 \pm 0.08(10)$ & 102 \\
\hline Ventral posteromedial & $0.61 \pm 0.11(10)$ & $0.56 \pm 0.10(10)$ & 92 \\
\hline Gelatinosus & $0.72 \pm 0.12(10)$ & $0.76 \pm 0.14(10)$ & 106 \\
\hline Dorsolateral geniculate & $0.55 \pm 0.14(10)$ & $0.51 \pm 0.16(9)$ & 93 \\
\hline Ventrolateral geniculate & $0.79 \pm 0.18(10)$ & $0.77 \pm 0.27(9)$ & 97 \\
\hline \multicolumn{4}{|l|}{ Basal ganglia } \\
\hline Caudate putamen & $0.49 \pm 0.07(11)$ & $0.49 \pm 0.07(9)$ & 100 \\
\hline Globus pallidus & $0.62 \pm 0.11(9)$ & $0.73 \pm 0.12(10)$ & 118 \\
\hline Subthalamic nucleus & $1.12 \pm 0.28(9)$ & $1.01 \pm 0.36(7)$ & 90 \\
\hline Entopeduncular nuclcus & $0.48 \pm 0.14(10)$ & $0.54 \pm 0.10(10)$ & 112 \\
\hline \multicolumn{4}{|l|}{ Cortex } \\
\hline Frontal cortex & $1.36 \pm 0.17(11)$ & $1.44 \pm 0.27(9)$ & 106 \\
\hline Parietal cortex & $1.16 \pm 0.11(9)$ & $1.09 \pm 0.24(10)$ & 94 \\
\hline
\end{tabular}

"Frontal cortex sections contained parts of frontal cortex areas 1-3 which are primarily motor cortex. Parietal cortex sections contained parietal cortex areas 1 and 2 and parietal cortex hindlimb area, which are primarily sensorimotor cortex (see Zilles and Wree, 1985).

1986), and MUSC and FLU binding (Palacios and Kuhar, 1982) change with age. Thus, differences in GABA receptors between the $d t$ mutant and normal rats could reflect a developmental failure in the cerebellum rather than an active receptor downregulation. This seems unlikely, as MUSC binding in other areas of the neuraxis appears to develop normally. In addition, the direction of change for MUSC binding in the DCN during development is toward decreased binding. Thus, higher, rather than lower, levels of binding would be expected if development of the DCN were retarded in the $d t$ rat.

Retarded development of $d t$ rats could also result in artifactual changes in the apparent receptor density duc to the differential quenching of ${ }^{3} \mathrm{H} \beta$ emissions by myelinated and unmyelinated tissue (Kuhar et al., 1986). As myelination increases during development, increased quenching could result in apparent decreases in receptor density. The receptor changes noted in the DCN are, however, in the direction opposite that which would be expected if myelination were retarded in $d t$ rats. Furthermore, the negative findings in other regions and with other ligands argue against a general effect of differential quenching due to altered myelination.

In addition to the $\mathrm{GABA}$ receptor complex, muscarinic, 5- $\mathrm{HT}_{2}$,

\begin{tabular}{|c|c|c|c|}
\hline \multirow[b]{2}{*}{ Brain area } & \multicolumn{3}{|c|}{${ }^{3} \mathrm{H}-\mathrm{QNB}$ binding (pmol/mg protein) } \\
\hline & $\begin{array}{l}\text { Normal } \\
\text { littermate }(N)\end{array}$ & Dystonic $(N)$ & $\begin{array}{l}\% \\
\text { Normal }\end{array}$ \\
\hline Pontine nuclei & $2.63 \pm 0.39(10)$ & $2.81 \pm 0.43(10)$ & 107 \\
\hline Substantia nigra & $0.37 \pm 0.03(10)$ & $0.38 \pm 0.05(9)$ & 103 \\
\hline Caudate putamen & $3.22 \pm 0.34(11)$ & $3.42 \pm 0.50(9)$ & 106 \\
\hline Frontal cortex & $2.71 \pm 0.31(11)$ & $2.85 \pm 0.47(9)$ & 105 \\
\hline Parietal cortex & $2.66 \pm 0.25(11)$ & $2.95 \pm 0.47(9)$ & 111 \\
\hline Nucleus accumbens & $3.30 \pm 0.33(11)$ & $3.38 \pm 0.50(9)$ & 102 \\
\hline
\end{tabular}

Table 5. Muscarinic cholinergic receptor density in 25-d-old dystonic ${ }^{3} \mathrm{H}-\mathrm{QNB}$ binding (pmol/mg protein) 

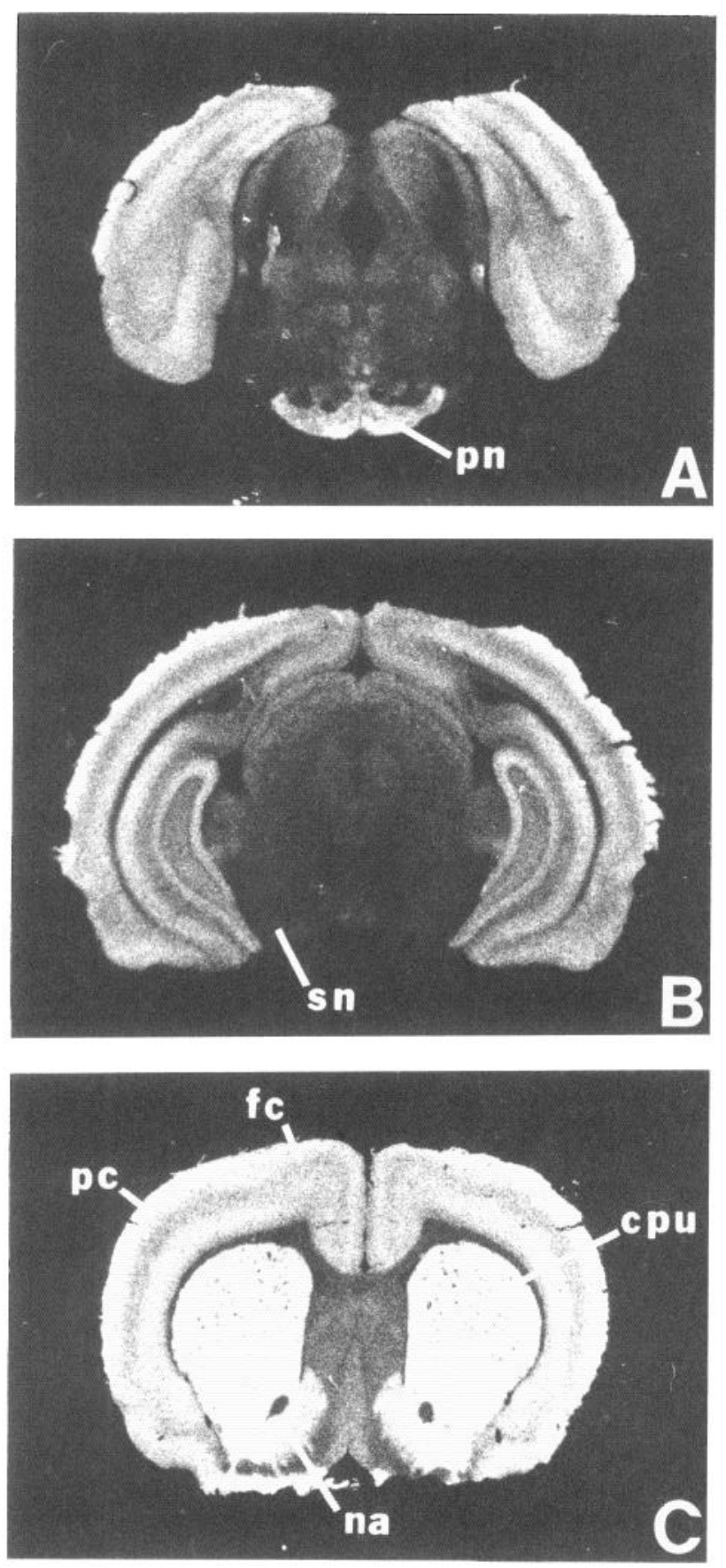

Figure 3. ${ }^{3} \mathrm{H}-\mathrm{QNB}$ binding in a $d t$ rat. QNB ( $1 \mathrm{~nm}$ ) was used to label the muscarinic cholinergic receptor. $A-C$, The 3 levels at which binding was quantified. There were no differences in binding between normal and $d t$ rats, and no nonspecific binding (measured in the presence of 1 $\mu \mathrm{M}$ atropine) was detected. Abbreviations: $f c$, frontal cortex; $p c$, parietal cortex. See Figure 1 for other abbreviations.

and $D_{2}$ receptors were examined in selected brain areas. The binding profiles for these receptors did not differ between $d t$ and normal animals and were comparable to the binding patterns reported by others (Palacios et al, 1981; Wamsley et al., 1981; Richfield et al., 1986; Miyoshi et al., 1987). These results support previous findings that most neurochemical and anatomical conditions in the $d t$ mutant appear normal (Lorden et al., 1984; McKeon et al., 1984). The primary exception is the cerebellum,
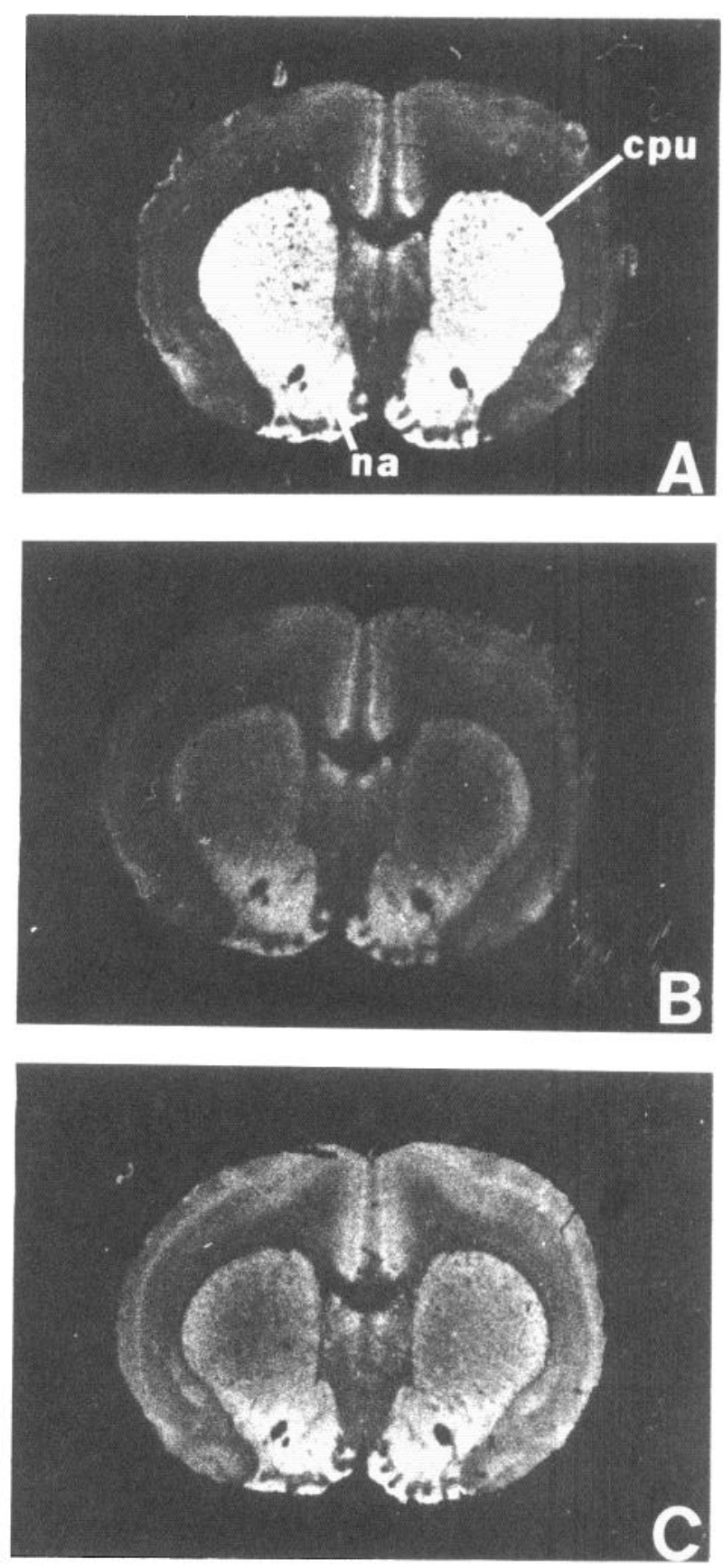

Figure 4. ${ }^{3} \mathrm{H}$-spiroperidol binding in a $d t$ rat. SPIRO $(0.8 \mathrm{~nm})$ was used to label both dopamine $\mathrm{D}_{2}$ and serotonin $5-\mathrm{HT}_{2}$ receptors. $A$, Binding in the presence of $100 \mathrm{~nm}$ mianserin shows the distribution of $\mathrm{D}$, receptors. $C$, Binding in the presence of $100 \mu \mathrm{m}$ dopamine shows the distribution of 5- $\mathrm{HT}_{2}$ receptors. $B$, Binding in the presence of both 100 $\mathrm{nM}$ mianserin and $100 \mu \mathrm{M}$ dopamine shows nonspecific binding. No differences between $d t$ and normal rats were found for either dopamine or $5-\mathrm{HT}_{2}$ receptors in the areas studied. See Figure 1 for abbreviations.

where several neurochemical anomalies exist. These include, in addition to the GABAergic changes, increased norepinephrine and decreased cGMP levels (Lorden et al., 1985; McKeon et al., 1986), both of which could contribute to, or reflect, altered Purkinje cell function (Biggio et al., 1977a, b; Moises et al., 1979; Yeh et al., 1981; Yeh and Woodward, 1983a, b). A recent metabolic mapping study of the brains of $d t$ and normal rats (Brown and Lorden, 1989) also revealed a significant increase 
Table 6. Dopamine $\mathrm{D}_{2}$ and serotonin $5-\mathrm{HT}$, receptor density in 25 -d-old dystonic and normal rats using the ligand ${ }^{3} \mathrm{H}$-spiroperidol (mean $\pm \mathrm{SD}$ )

\begin{tabular}{|c|c|c|c|c|}
\hline \multirow[b]{3}{*}{ Brain area } & \multicolumn{4}{|c|}{ Receptor density (fmol/mg protein) } \\
\hline & \multicolumn{2}{|l|}{ Dopamine } & \multicolumn{2}{|l|}{ Serotonin } \\
\hline & $\begin{array}{l}\text { Normal } \\
\text { littermate }(N)\end{array}$ & Dystonic $(N)$ & $\begin{array}{l}\text { Normal } \\
\text { littermate }(N)\end{array}$ & Dystonic $(N)$ \\
\hline Cortex & $27 \pm 15(11)$ & $36 \pm 18(8)$ & $37 \pm 17(11)$ & $44 \pm 19(8)$ \\
\hline Caudate putamen & $214 \pm 30(11)$ & $228 \pm 25(8)$ & $15 \pm 8 \quad(11)$ & $21 \pm 9$ \\
\hline Nucleus accumbens & $129 \pm 19(11)$ & $147 \pm 37(8)$ & $36 \pm 15(11)$ & $43 \pm 28(8)$ \\
\hline
\end{tabular}

in glucose utilization in the DCN of mutant rats in comparison with normal controls. Thus, abnormal Purkinje cell output to the DCN seems likely to play a major role in the movement disorder of the $d t$ mutant.

In contrast to the increased Purkinje cell activity suggested by the enzymatic and receptor data, extracellular unit recordings from Purkinje cells indicate reduced activity in these neurons in 25-d-old $d t$ rats (Stratton et al., 1988). It is possible that any hyperactivity in the Purkinje cells is associated with dystonic episodes and is prevented by the anesthesia used during electrical recordings. Alternatively, changes in GAD activity might lag behind changes in Purkinje cell activity. This appears to be the case in animals with lesions of the inferior olive which destroy the climbing fiber projection to the cerebellar cortex. After the lesion, Purkinje cell simple spike activity more than doubles (Batini and Billard, 1985), then declines to more normal levels by 10-14 d postlesion (Batini et al., 1985). Over this period GAD activity in the DCN increases, reaching a peak about 14 dayṣ postlesion (Oltmans et al., 1985; Sukin et al., 1987). Although GAD activity eventually begins to return toward normal, it remains elevated well after a substantial decline in single-cell activity. Thus, in the lesioned animals, the changes in GAD activity, once induced, persist beyond the period of major alterations in cell activity. A similar transient elevation of Purkinje cell activity early in the life of the $d t$ mutant might likewise result in increased GAD activity and decreased GABA receptor density which persist after the Purkinje cell firing rate has declined.

A growing body of data suggests that Purkinje cell input to the DCN is altered in $d t$ rats. In the rats with climbing fiber lesions discussed above, altered Purkinje cell activity results in changes in the firing rate of efferent neurons of the DCN (Batini et al., 1985) and atypical neural activity at DCN projection sites (Billard and Daniel, 1985). Similar changes in the cerebellar efferents of $d t$ rats might produce receptor changes in DCN projection sites. In the current study, we examined this possibility by analyzing GABA binding in the inferior olive. Recent work has revealed a GABAergic projection from the DCN to the inferior olive (Nelson and Mugnaini, 1989), and reduced activity in this system might produce GABA receptor up-regulation in the olive. Autoradiograms for both MUSC (Fig. 1, $A, B)$ and FLU (not shown), however, revealed a conspicuous lack of binding of either ligand in the olive. Thus, GABA afferents to the olive from the DCN and other regions (Nelson et al., 1984; deZeeuw et al., 1988; Angaut and Sotelo, 1989) may act via receptors not labeled using our methods. We also examined receptor status at several other DCN projection sites, including the red nucleus, pontine nuclei, and ventral thalamus
(Flumerfelt et al., 1973; Caughell and Flumerfelt, 1977; Faull and Carman, 1978; Herkenham, 1979; Haroian et al., 1981; Flumerfelt and Hrycyshyn, 1985; Angaut et al., 1986; Border et al,, 1986). No changes in the binding of any of the ligands used (FLU, MUSC, QNB) were seen.

The rat mutant under study was named dystonic because of the twisting postures that are the most obvious symptom of the disease. The absence of identifiable morphological lesions in the $d t$ mutant is also consistent with conditions found in idiopathic torsion dystonia in humans (Eldridge, 1970; Zeman, 1970). In humans, dystonia has been postulated to be a disorder of the basal ganglia. This assumption is based, in part, on the observation that drugs capable of producing dystonic symptoms (e.g., neuroleptics) frequently can be shown to have an effect in this area (Crane and Naranjo, 1971; Rupniak et al., 1986). Recent reports also suggest that secondary dystonia is associated with imaging (NMR, CAT) and autopsy findings indicating damage to the basal ganglia (Burton et al., 1984; Marsden et al., 1985; Berkovic et al., 1987). In primary dystonia, however, the evidence for an exclusive involvement of the basal ganglia is less certain. Postmortem studies and imaging techniques have failed to provide convincing evidence of basal ganglia lesions or have implicated cerebellar and other structures, as well as the basal ganglia (Eldridge, 1970; Zeman, 1970; Larsen et al., 1985; Stoessl et al., 1986; Hedreen et al., 1988). In addition, focal dystonias (writer's cramp, torticollis) have recently been reported to be prominent features in patients with degenerative cerebellar ataxias and cerebellar atrophy (Fletcher et al., 1988). In many cases, however, there is no evidence of anatomical abnormalities. In the $d t$ rat, where many of the features of the motor disorder resemble those seen in human dystonia (Lorden et al., 1984), neither neurochemical nor anatomical abnormalities in basal ganglia structures have been identified (McKeon et al., 1984). The current study did suggest the possibility that GABA/BZD receptors in the globus pallidus might be increased. The marginal nature of this effect, however, requires not only that it be confirmed, but that substantial caution be exercised in the drawing of inferences. Indeed, the observed conditions may reflect secondary changes caused by the dystonic disorder, rather than factors contributing to the disorder. Reduced or delayed myelination in $d t$ rats could also contribute to the apparent increase in receptor density in this heavily myelinated region as discussed above. What is clear is that a dysfunction in the cerebellum exists in the $d t$ rat. Specification of the relationship of this abnormality to the motor syndrome may provide valuable information not only about the role of the cerebellum in regulating movement, but about the mechanisms by which genetic errors can become manifest in unusual neurological profiles. 


\section{References}

Angaut P, Sotelo C (1989) Synaptology of the cerebello-olivary pathway. Double labelling with anterograde axonal tracing and GABA immunocytochemistry in the rat. Brain Res 479:361-365.

Angaut P, Batini C, Billard, JM, Daniel H (1986) The cerebellorubral projection in the rat: retrograde anatomical study. Neurosci Lett 68: 63-68.

Banerjee SP, Kung LS, Riggi S, Chanda SK (1977) Development of $\beta$-adrenergic receptor subsensitivity by antidepressants. Nature 268 : $455-456$.

Batini C, Billard IM (1985) Release of cerebellar inhibition by climbing fiber deafferentation. Exp Brain Res 57:370-380.

Batini C, Billard JM, Daniel H (1985) Long-term modification of cerebellar inhibition after inferior olive degeneration. Exp Brain Res 59:404-409.

Berkovic SF, Karpati G, Carpenter S, Lang AE (1987) Progressive dystonia with bilateral putaminal hypodensitics. Arch Neurol 44: $1184-1187$.

Biggio G, Brodie BB, Guidotti A (1977a) Mechanisms by which diazepam, muscimol, and other drugs change the content of cGMP in cerebellar cortex. Proc Natl Acad Sci USA 74:3592-3596.

Biggio G, Costa E, Guidotti A (1977b) Pharmacologically induced changes in $3^{\prime}, 5^{\prime}$-cyclic guanosine monophosphate content of rat cerebellar cortex: differences between apomorphine, haloperidol and harmaline. J Pharmacol Exp Ther 200:207-215.

Billard JM, Daniel H (1985) Inferior olive destruction induces disfacilitation of the red nucleus activity. Brain Res 336:372-375.

Blair LAC, Levitan ES, Marshall J, Dionne VE, Barnard EA (1988) Single subunits of the $\mathrm{GABA}_{\triangle}$ receptor form ion channels with properties of the native receptor. Science 242:577-579.

Border BG, Kosinski RJ, Azizi SA, Mihailoff GA (1986) Certain basilar pontine afferent systems are GABA-ergic: combined HRP and immunocytochemical studies in the rat. Brain Res Bull 17:169-179.

Bowery NG, Hudson AL, Price GW (1987) GABA and GABA Ge- $_{A}$ ceptor site distribution in the rat central nervous system. Neuroscience 20:365-383.

Brown LL, Lorden JF (1989) Regional cerebral glucose utilization reveals widespread abnormalities in the motor system of the rat mutant dystonic. J Neurosci 9:4033-4041.

Burton K, Farrell K, Li D, Calne DB (1984) Lesions of the putamen and dystonia: CT and magnetic resonance imaging. Neurology 34: 962-965.

Caughell KA, Flumerfelt BA (1977) The organization of the cerebellorubral projection: an experimental study in the rat. J Comp Neurol 176:295-306.

Crane GE, Naranjo ER (1971) Motor disorders induced by neuroleptics. Arch Gen Psychiatry 24:179-184.

deZeeuw CI, Holstege JC, Calkoen F, Ruigrok TJH, Voogd J (1988) A new combination of WGA-HRP anterograde tracing and GABA immunocytochemistry applied to afferents of the cat inferior olive at the ultrastructural level. Brain Res 447:369-375.

Eldridge R (1970) The torsion dystonias: literature review and genetic and clinical studies. Neurology 20:1-78.

Faull RLM, Carman JB (1978) The cerebellofugal projections in the brachium conjunctivum of the rat. I. The contralateral ascending pathway. J Comp Neurol 178:495-518.

Fletcher NA, Stell R, Harding AE, Marsden, CD (1988) Degenerative cerebellar ataxia and focal dystonia. Mov Disord 3:336-342.

Flumerfelt BA, Hrycyshyn AW (1985) Prccercbellar nuclei and red nucleus. In: The rat nervous system (Paxinos G, ed), Vol 2, pp 221250. Orlando, FL: Academic.

Flumerfelt BA, Otabe S, Courville J (1973) Distinct projections to the red nucleus from the dentate and interposed nuclei in the monkey. Brain Res 50:408-414.

Fonnum F, Storm-Mathisen J, Walberg F (1970) Glutamate decarboxylase in inhibitory neurons: a study of the enzyme in Purkinje cell axons and boutons in the cat. Brain Res 20:259-275

Frostholm A, Rotter A (1987) The ontogeny of $\left[{ }^{3} \mathrm{H}\right]$ muscimol binding sites in the C57BL/6J mouse cerebellum. Dev Brain Res 37:157-166.

Fuchs K, Sieghart W (1989) Evidence for the existence of several different $\alpha$ - and $\beta$-subunits of the GABA/benzodiazepine receptor complex from rat brain. Neurosci Lett 97:329-333.

Garrett KM, Tabakoff B (1985) The devclopment of type I and type
II benzodiazepine receptors in the mouse cortex and cerebellum Pharmacol Biochem Behav 22:985-992.

Haroian AJ, Massopust LC, Young PA (1981) Cerebellothalamic projections in the rat: an autoradiographic and degeneration study. $J$ Comp Neurol 197:217-236

Hebebrand J, Friedl W, Propping P (1988) The concept of isoreceptors: application to the nicotinic acetylcholine receptor and the gammabutyric $\operatorname{acid}_{\mathcal{A}} /$ benzodiazepine receptor complex. J Neural Transm 71 : $1-9$

Hedreen JC, Zweig RM, DeLong MR, Whitehouse PJ, Price DL (1988) Primary dystonias: a review of the pathology and suggestions for new directions of study. Adv Neurol 50:123-132.

Herkenham M (1979) The afferent and efferent connections of the ventromedial thalamic nucleus in the rat. J Comp Neurol 183:487518

Herkenham M (1987) Mismatches between neurotransmitter and receptor localizations in brain: observations and implications. Neuroscience 23:1-38.

Jones EG (1985) The thalamus. New York: Plenum.

Kuhar MJ, deSouza EB, Unnerstall JR (1986) Neurotransmitter receptor mapping by autoradiography and other methods. Annu Rev Neurosci 9:27-59.

Larsen TA, Dunn HG, Jan JE, Calne DB (1985) Dystonia and calcification of the basal ganglia. Neurology 35:533-537.

Larson E, Howlett B, Jagendorf A (1986) Artificial reductant enhancement of the Lowry method for protein determination. Anal Biochem 155:243-248.

Levitan ES, Blair LAC, Dionne VE, Barnard EA (1988a) Biophysical and pharmacological properties of cloned $\mathrm{GABA}_{\mathrm{A}}$ receptor subunits expressed in Xenopus oocytes. Neuron 1:773-781.

Levitan ES, Schofield PR, Burt DR, Rhee LM, Wisden W, Kohler M Fujita N, Rodriguez HF, Stephenson A, Darlison MG, Barnard EA Seeburg PH (1988b) Structural and functional basis for GABA receptor heterogeneity. Nature 335:76-79.

Lippa AS, Sano MC, Coupet J, Klepner CA, Beer B (1978) Evidence that benzodiazepine receptors reside on cerebellar Purkinje cells: studies with "nervous" mutant mice. Life Sci 23:2213-2218.

Lorden JF, McKeon TW, Baker HJ, Cox N, Walkley SU (1984) Characterization of the rat mutant dystonic $(\mathrm{dt})$ : a new animal model of dystonia musculorum deformans. J Neurosci 4:1925-1932.

Lorden JF, Oltmans GA, McKeon TW, Lutes J, Beales M (1985) Decreased cerebellar cGMP levels and insensitivity to harmaline in the genetically dystonic rat. J Neurosci 5:2618-2625.

Lowry OH, Rosebrough NJ, Farr AL, Randall RJ (1951) Protein measurement with the Folin phenol reagent. J Biol Chem 193:265275.

Marsden CD, Obeso JA, Zarranz JJ, Lang AE (1985) The anatomical basis of symptomatic hemidystonia. Brain 108:463-483.

McKeon TW, Lorden JF, Oltmans GA, Walkley SU (1984) Decreased catalepsy response to haloperidol in the dystonic (dt) rat. Brain Res 308:89-96.

McKeon TW, Lorden JF, Oltmans GA, Beales M (1986) Alterations in the noradrenergic projection to the cerebellum in the genetically dystonic rat. Brain Res 366:89-97.

Miyoshi R, Kito S, Shimazu M, Matsubayashi H (1987) Ontogeny of muscarinic receptor sites in the rat brain with emphasis on the differentiation of $\mathbf{M}_{1}$ and $\mathrm{M}_{2}$ subtypes-semiquantitative in vitro autoradiography. Brain Res 420:302-312.

Moises HD, Woodward DH, Hoffer BJ, Freedman R (1979) Interactions of norepinephrine with Purkinje cell responses to putative amino acid neurotransmitters applied by microiontophoresis. Exp Neurol 64:493-515.

Nelson BJ, Mugnaini E (1989) Origins of GABAergic inputs to the inferior olive. In: Experimental brain research series, Vol 17: the olivocerebellar system in motor control (Strata P, ed), pp 86-87. Berlin: Springer-Verlag.

Nelson B, Barmack NH, Mugnaini E (1984) A GABAergic cerebelloolivary projection in the rat. Soc Neurosci Abstr 10:539.

Olson JMM, Greenamayre JT, Penney JB, Young AB (1987) Autoradiographic localization of cerebellar excitatory amino acid binding sites in the mouse. Neuroscience 22:913-923.

Oltmans GA, Beales M, Lorden JF, Gordon J (1984) Increased glutamic acid decarboxylase activity in the deep cerebellar nuclei of the dystonic (dt) rat. Exp Neurol 85:216-222. 
Oltmans GA, I orden JF, Reales M (1985) I esions of the inferior olive increase glutamic acid decarboxylase in the deep cerebellar nuclei of the rat. Brain Res 347:154-158.

Oltmans GA, Beales M, Lorden JF (1986) Glutamic acid decarboxylase activity in micropunches of the deep cerebellar nuclei of the genetically dystonic (dt) rat. Brain Res 385:148-151.

Palacios JM, Kuhar MJ (1982) Onlogeny of high-affinity GABA and benzodiazepine receptors in the rat cerebellum: an autoradiographic study. Dev Brain Res 2:531-539.

Palacios JM, Young WS, Kuhar MJ (1980) Autoradiographic localization of gamma-aminobutyric acid (GABA) receptors in the rat cerebellum. Proc Natl Acad Sci USA 77:670-674.

Palacios JM, Niehoff DL, Kuhar MJ (1981) [ ${ }^{3} \mathrm{H}$ ]Spiperone binding sites in brain: autoradiographic localization of multiple receptors. Brain Res 2.13:277-28.

Palkovits M (1973) Isolated removal of hypothalamic or other brain nuclei of the rat. Brain Res 59:449-450.

Pan HS, Frey KA, Young AB, Penney JB (1983) Changes in $\left[{ }^{3} \mathrm{H}\right]-$ muscimol binding in substantia nigra, entopeduncular nucleus, globus pallidus and thalamus after striatal lesions as demonstrated by quantitative receptor autoradiography. J Neurosci 6:1189-1198.

Pan HS, Penney JB, Young AB (1984) Characterization of benzodiazepine receptor changes in substantia nigra, globus pallidus, and entopeduncular nucleus after striatal lesions. J Pharmacol Exp Ther 230:768-775

Pan HS, Penney JB, Young AB (1985) Gamma amino butyric acid and benzodiazepine receptor changes induced by unilateral 6-hydroxydopamine lesions of the medial forebrain bundle. J Neurochem 45:1396-1404.

Paxinos G, Watson C (1986) The rat brain in stereotaxic coordinates, 2nd ed. Orlando, FL: Academic.

Penney JB, Pan HS, Young AB, Frey KA, Dauth GW (1981) Quan titative autoradiography of $\left[{ }^{3} \mathrm{H}\right]$ muscimol binding in rat brain. Science 214:1036-1038.

Peroutka SJ, Snyder SH (1980) Regulation of serotonin, $\left(5-\mathrm{HT}_{2}\right)$ receptors labelled with [ $\left.{ }^{3} \mathrm{H}\right]$-spiroperidol by chronic treatment with the antidepressant amitriptyline. J Pharmacol Exp Ther 215:582-587.

Pritchett DB, Sontheimer H, Gorman CM, Kettenmann H, Seeburg $\mathrm{PH}$, Schofield PR (1988) Transient expression shows ligand gating and allosteric potentiation of GABA , receptor subunits. Science 242: 1306-1308.

Richfield EK, Young AB, Penney JB (1986) Properties of $D_{2}$ dopamine receptor autoradiography: high percen tage of high-affinity agonist sites and increased nucleotide sensitivity in tissue sections. Brain Res 383: 121-128.

Rotter $\Lambda$, Frostholm A (1986) Cerebellar benzodiazepine receptor distribution: an autoradiographic study of the normal C57BL/6J and Purkinje cell degeneration mutant mouse. Neurosci Lett 71:66-71.

Rotter A, Frostholin A (1988) Cerebellar benzodiazepine receptors: cellular localization and consequences of neurological mutations in mice. Brain Res 444:133-146.

Rotter A, Gorenstein C, Frostholm A (1988) The localization of GABA A receptors in mice with mutations affecting the structure and connectivity of the cerebellum. Brain Res 439:236-248.

Rupniak NMJ, Jenner P, Marsden CD (1986) Acute dystonia induced by neuroleptic drugs. Psychopharmacology 88:403-419.

Sauer G, Wille W, Müller WE (1984) Binding studies in the lurcher mutant suggest an uneven distribution of putative benzodiazepine receptor subclasses in the mouse cerebellum. Neurosci Lett 48:333338.

Schwartz RD (1988) The GABA , receptor-gated ion channel: biochemical and pharmacological studies of structure and function. Biochem Pharmacol 37:3369-3375.

Siegel R (1988) The mRNAs encoding $\mathrm{GABA}_{\mathrm{A}}$ /benzodiazepine re- ceptor subunits are localized in different cell populations of the bovine cerebellum. Neuron 1:579-584.

Sieghart W (1986) Comparison of benzodiazepine receptors in cerebellum and inferior colliculus. $J$ Neurochem 47:920-923.

Skolnick P, Syapin PJ, Paugh BA, Paul SM (1979) Reduction in benzodiazepine receptors associated with Purkinje cell degeneration in "nervous" mutant milce. Nature 277:397-399.

Stephenson FA (1988) Understanding the GABA 、 receptor: a chemically gated ion channel. Biochem J 249:21-32.

Stoessl AJ, Martin WRW, Clark C, Adam MJ, Ammann W, Beckman JH, Bergstrom M, Harrop R, Rogers JG, Ruth TJ, Sayre CI. Pate BD, Calne DB (1986) PET studies of cerebral glucose metabolism in idiopathic torticollis. Neurology 36:653-657.

Stratton SE, Lorden JF, Mays LE, Oltmans GA (1988) Spontaneous and harmaline-stimulated Purkinje cell activity in rats with a genetic movement disorder. J Neurosci 8:3327-3336.

Sukin D, Skedros DG, Beales M, Stratton SE, Lorden JF, Oltmans GA (1987) Temporal sequence of motor disturbances and increased cer ebellar glutamic acid decarboxylase activity following 3-acetylpyridine lesions in adult rats. Brain Res 426:82-92.

Unnerstall JR, Kuhar MJ, Niehoff DL, Palacios JM (1981) Benzudiazepine receptors are coupled to a subpopulation of gamma-aminobutyric acid (GABA) receptors: evidence from a quantitative autoradiographic study. J Pharmacol Exp Ther 218:797-804.

U'Prichard DC, Snyder SH (1978) ' $\mathrm{H}$-Catecholamine binding to $\alpha$-receptors in rat brain: enhancement by reserpine. Eur J Pharmacol 51: 145-155.

U'Prichard DC, Reisine TD, Mason ST, Fibiger HC, Yamamura HI (1980) Modulation of rat brain $\alpha$ - and $\beta$-adrenergic receptor populations by lesion of the dorsal noradrenergic bundle. Brain Res 187: 143-154.

Wamsley JK, Lewis MS, Young WS, Kuhar MJ (1981) Autoradiographic localization of muscarinic cholinergic receptors in rat brainstem. J Neurosci 1:176-191

Wassef M, Simons J, Tappaz ML, Sotelo C (1986) Non-Purkinje cell GABAergic innervation of the deep cerebellar nuclei: a quantitative immunocytochemical study in C57BL and in Purkinje cell degeneration mutant mice. Brain Res 399:125-135

Wisden W, Morris BJ, Darlison MG, Hunt SP, Barnard EA (1988) Distinct $\mathrm{GABA}_{\mathrm{A}}$ receptor $\alpha$-subunit mRNAs show differential patterns of expression in bovine brain. Neuron 1:937-947.

Wisden W, Morris BJ, Darlison MG, Hunt SP, Barnard EA (1989) Localization of GABA, receptor $\alpha$-subunit mRNAs in relation 10 receptor subtypes. Mol Brain Res 5:305-310.

Yeh HH, Woodward DJ (1983a) Noradrenergic action in the developing rat cerebellum: interaction between norepinephrine and gamma-aminobutyric acid applied microiontophoretically to immature Purkinje cells. Dev Brain Res 10:49-62.

Yeh HH, Woodward DJ (1983b) Noradrenergic action in the developing rat cerebellum: interaction between norepinephrine and synaptically-evoked responses of immature Purkinje cells. Dev Brain Res 11:207-218.

Yeh HH, Moises HC, Waterhouse BD, Woodward DJ (1981) Modulatory interactions between norepinephrine and taurine, beta-alanine, gamma-aminobutyric acid and muscimol, applied iontophoretically to cerebellar Purkinje cells. Neuropharmacology 20:629-639.

Young WS, Kuhar MJ (1979) Autoradiographic localization of benzodiazepine receptors in the brains of humans and animals. Nature 280:393-395.

Zeman W (1970) Pathology of the torsion dystonias (dystonia musculorum deformans). Neurology 20:79-88.

Zilles K, Wree A (1985) Cortex: areal and laminar structure. In: The rat nervous system (Paxinos G, ed), Vol. 1, pp 375-415. Orlando, FL: Academic. 